\title{
Perceptions Towards Integrating Desire2Learn System in EFL Teaching and Learning Processes
}

\author{
Eman Abdel-Reheem Amin ${ }^{1}$ \& Faiza Abdalla ELhussien Mohammed ${ }^{1}$ \\ ${ }^{1}$ English language department, Zulfi College of Education, Majmaah University, Saudi Arabia \\ Correspondence: Eman Abdel-Reheem Amin, English language department, Majmmah University, Majmaah \\ 11952, Saudi Arabia. Tel: 966-505-720-758. E-mail: drimanbro@gmail.com, e.abdelrahim@mu.edu.sa
}

Received: June 2, 2018 Accepted: August 4, 2018 Online Published: August 6, 2018

doi: 10.5539/elt.v11n9p1 URL: http://doi.org/10.5539/elt.v11n9p1

\begin{abstract}
This study applied the Technology Acceptance Model (TAM) in investigating teachers and students' perceptions towards integrating the D2L system to enhance EFL teaching and learning processes at the English language department, Majmaah University. Two close-ended questionnaires were designed to measure the participants' perceived ease of use, perceived usefulness, attitudes, and intentions to use D2L. To understand participants' perceptions and the obstacles that may hinder their use of D2L, an interview with open-ended questions were conducted. Data from the questionnaires were analyzed using SPSS. Qualitative analysis of the interview data showed the frequencies and proportions of participants' responses. The findings indicated that the D2L system is totally accepted by teachers and students. Few problems along with their suggested solutions were grouped, presented and discussed.
\end{abstract}

Keywords: Desire2Learn, EFL teaching and learning processes, Majmaah University, Technology Acceptance Model

\section{Introduction}

\subsection{Background}

Technology integration in teaching and learning has become one of the modern aspects of education, especially in higher education. An example of this integration is the use of Learning Management systems (LMS) inside universities. LMS is an integrated software system responsible for the management of the educational and learning process (Pina, 2013). LMS has been widely used to enrich and supplement teaching and learning in most universities all over the world. The Ministry of Higher Education in Saudi Arabia encouraged its use among universities (Alebaikan \& Troudi, 2010). Majmaah University has tried to increase both teachers and students' use of one of these LMS, namely, Desire2Learn (D2L).

Integrating and adopting learning management systems in teaching and learning has undergone through different theories and a wide range of applications. Successful integration and use of new learning or teaching system are determined by some factors such as acceptance, attitudes, motivation, perceived ease of use, perceived usefulness, and behavioral intentions. Investigating the acceptance of technologies in teaching and learning among teachers and students has been a subject of many previous studies such as Alrafi (2009), Chen (2010), Wang (2010), Kung-Teck, Rosma, Pauline, and Mohd, (2013) and Park (2009). Some models are used to explore and explain factors that affect individuals' acceptance or rejection of new technologies, for example, the Matching Person, Technology Model (MPT), and the Technology Acceptance Model (TAM) (Timothy, 2008 \& Venkatesh \& Bala, 2008).

\section{Literature Review}

\subsection{The Technology Acceptance Model (TAM)}

Based on the Theory of Reasoned Actions (TRA), the Technology Acceptance Model (TAM) was developed by Davis (1989). TRA and TAM assume that if learners have the intention to perform an action, they will definitely do it. TAM is defined by Timothy (2008) as a model of acceptance of online social networking system. The TAM measures users' acceptance and usage of technology. It suggests that when users are exposed to new technology, some factors affect their willingness to use it. Referring to the TAM model, perceived usefulness (PU) and perceived ease of use (PEOU) are two major influential factors on user's attitude towards adopting technology 
and then users' attitude influence intention to use new technology (G. B. Davis \& F. D. Davis, 2003). Accordingly, four elements shape the TAM and are considered the major constructs by which the acceptance of new technology is measured. They are perceived usefulness, perceived ease of use, attitudes, and behavioral intentions.

\subsection{Perceived Usefulness (PU)}

Perceived usefulness is one of the principal constructs of TAM. PU is the degree to which someone believes that using technology may enhance their performance in learning or in working. Perhaps using technology is useful, but it may be difficult to use. Thus, the benefits of usefulness could be threatened by the difficulty to use technology applications (G. B. Davis \& F. D. Davis, 2003). The results of Teo, Wong, and Chai (2008) showed that perceived usefulness has a positive effect on teachers' intention to use technology. Ku (2009) concluded that perceived usefulness is the major factor that affected learners retain in a web-based online course.

\subsection{Perceived Ease of Use (PEOU)}

Perceived ease of use is TAM's second belief construct. PEOU is the extent to which someone agrees that the system will be effortless. Furthermore, perceived ease of use influences intentions to use technology, indirectly, through attitude. Perceived ease of use has only one direction towards perceived usefulness. On the other hand, there are direct and indirect effects of perceived ease of use on behavioral intention (Teo, 2009; 2011). Further, some researchers have tried to investigate how and why perception forms and changes. In his study, Venkatesh (2000) presented and tested a model that proposes the internal and external control, intrinsic motivation, and emotion as the main factors of early perceptions about the ease of use of any new system. The results of Sarfraz, Mansoor, and Tariq (2015) indicated teachers and students' positive perceptions of CLT in a CALL environment.

\subsection{Attitude Towards Technology Integration in Classrooms}

Attitude towards technology integration in classrooms is the third construct of the TAM. It refers to users' attitude towards technology integration in the teaching and learning processes. A range of studies was carried out to investigate teachers' attitude towards integrating technology in their classrooms. The results indicated that when teachers are informed about the effectiveness of computers in classrooms, their attitudes are affected positively (Teo, 2006). The study of Keller, Hrastinski and Carlsson (2007) concluded that perceived usefulness, perceived ease of use, and students' beliefs about the relationship between technology and learning influenced acceptance positively.

\subsection{Behavioral Intention}

Behavioral intention is the fourth construct of the TAM. It refers to users' intentional behavior or willingness to use new technology. Perceived ease of use and perceived usefulness are two principal components of users' behavioral intention to use any new technology (Muller, 2013). Higher education seriously works to integrate e-system that maintains the students to access online learning contents easily. Therefore, studies are needed to investigate the intention and acceptance of learners towards the use of technology in learning and teaching environment. For example, Park (2009) concluded that understanding the reasons behind learners' behavioral intention to use new learning electronic system would help universities' managers in creating a mechanism to attract students to adopt this learning environment.

Sheng (2008) investigated learners' attitudes, satisfaction, behavioral intentions, and the effectiveness of the Blackboard e-learning system. Results indicated that learners' behavioral intention to use the e-learning system was affected by perceived usefulness and perceived satisfaction. Following the same line of research, the proposed research aims at investigating teachers and learners' perception of D2L. Further, it examines teachers and students' attitudes and intentions towards D2L use.

\subsection{Desire to Learning (D2L)}

The Desire to Learn (D2L) is an online learning management system (LMS), which allows interaction between teachers, students, and their courses, through the synchronous and asynchronous features (Fahrni, Rudolph \& De Schutter, 2004). D2L, also, offers an e-learning environment through which educators can achieve their goals, missions, and visions. Desire2Learn tools serve learners around the world, including higher education and other institutions (Kitchener \& Orlando, 2008). Alrafi (2009) claimed that successful implementation of any system depends on the acceptance or the rejection by its users. D2L gains an excellent reputation among educational institutions since it offers significant educational tools for instructors and their students.

\subsection{Desire to Learn (D2L) Components, Usefulness, and Use}

D2L offers a variety of options that help users in reviewing and rating its teaching and learning materials such as 
content files, discussions, forums, quizzes, and grades. Moreover, documents and videos can be either viewed online or downloaded. It also maintains discussion forums to create an interactive learning environment where instructors, and students and their classmates can discuss course materials and questions. Besides, the dropbox allows students to upload course assignments (QuickStart D2L Guide, 2012). Furthermore, D2L has features for assessment outcomes, since it has options for creating rubrics, surveys, and grading system. LMS, among which is D2L, can store any course activity, whether a class discussion, exams, assignments, grades, and evaluation of learning outcomes. Further, D2L offers statistics and reports to help program administrators and staff members to achieve the accreditation of their departments and universities (Tello \& Motiwalla, 2010).

\section{Research problem and questions}

Most of the studies in the field of English language learning have emphasized the advantages of using technology in the classroom as argued by (Palloff \& Pratt, 2013), who pointed out that technology played a central role in the education process in the modern society. Although the D2L system has advantages in the teaching and learning processes, few studies have investigated its acceptance. For example, the study of Fahrni, Rudolph and De Schutter (2004) concluded that D2L is easy to integrate with teaching classes and has a high degree of usability. In the Saudi context, the integration of D2L in EFL teaching and learning has not yet been investigated. Due to its importance, teachers and students at Majmaah University were trained on the use of D2L. Therefore, this research attempts to identify teachers and students' perceptions and attitudes towards integrating D2L in EFL classrooms. It examines their perceptions of D2L through their perceived ease of use, perceived usefulness, attitudes, and intentions to use and integrate D2L in their EFL teaching and learning processes. Moreover, it investigates the problems that may hinder the participants' use of the D2L system. Understanding their perceptions, problems, and suggestion may be beneficial for educational institutions aiming at integrating D2L in their teaching and learning processes.

Accordingly, the present research seeks answers to the following questions:

1) What are teachers' perceptions towards integrating D2L in their EFL teaching process?

2) What are teachers' attitudes and intentions towards integrating D2L in their EFL teaching process?

3) What are students' perceptions towards integrating D2L in their EFL learning process?

4) What are students' attitudes and intentions towards integrating D2L in their EFL learning process?

5) What are some problems that may hinder teachers and students' use of the D2L system?

6) What are some suggested solutions to such problems?

\section{Methodology}

\subsection{Participants}

Participants are from Zulfi College of Education, English language department, Majmaah University, KSA. They are female and male demonstrators $(\mathrm{n}=10)$, lecturers $(\mathrm{n}=12)$, assistant professors $(\mathrm{n}=11)$ and students $(\mathrm{n}=240)$. The average age of the students is 20 . They are from level two to level eight to ensure that they have enough knowledge about using D2L. The staff members also are familiar with D2L uses and features.

4.2 Design

The proposed research adopts the survey study design and techniques to investigate participants' perceptions of a new methodology.

\subsection{Instruments}

Instruments of the study are two questionnaires and two interviews designed and conducted by the authors of the study. The tools represent the constructs of the TAM model and the context of using D2L.

\subsubsection{The Questionnaires}

Both questionnaires measured participants' responses on a five-Likert scale. Teachers' questionnaire aimed at investigating their perceptions of D2L integration in EFL teaching. Students' questionnaire examined their acceptance of using D2L in their learning process. Each questionnaire consisted of 40 items that explore their perceived ease of D2L use $(n=10)$, perceived usefulness of D2L $(n=10)$, attitudes towards using D2L $(n=10)$, and behavioral intention of using and integrating D2L in their future classes $(n=10)$.

\subsubsection{The Interviews}

The interviews were used to collect more detailed data about D2L integration and use in EFL teaching and learning processes. The first interview was with teachers and the second one was for the students. Each interview 
consisted of three open-ended questions. The first question was intended to elicit respondents' perceptions of integrating D2L in their English language teaching and learning processes. The second question aimed at finding out some problems that hinder the participants' use of D2L. Further, suggested solutions to such problems were obtained through the last question of the interview.

\subsection{Validity and Reliability}

The validity of the questionnaires was established by a jury of specialists in TEFL. Cronbach's alpha values were computed, via SPSS version 22, to measure the reliability of the questionnaires (Table. 1).

Table 1 . The reliability of the questionnaires

\begin{tabular}{lll}
\hline Dimensions & Cronbach's alpha & \\
\cline { 2 - 3 } & Teachers' questionnaire & Students' questionnaire \\
\hline PEU & 0.896 & 0.951 \\
PU & 0.891 & 0.951 \\
ATT & 0.713 & 0.835 \\
BI & 0.922 & 0.972 \\
Total & 0.956 & 0.96 \\
\hline
\end{tabular}

All variables show a high level of reliability with the Cronbach's alpha values (Table 1) exceeding the recommended 0.7 (Nunnally, 1978). This means that both the questionnaires are reliable.

The internal consistency of the questionnaires' dimensions was measured as presented in Table 2.

Table 2. The Correlation Coefficient between each dimension and the total score of the questionnaires

\begin{tabular}{lll}
\hline \multirow{2}{*}{ Dimensions } & \multicolumn{2}{l}{ Correlation with the total score of the questionnaire } \\
\cline { 2 - 3 } & Teachers' questionnaire & Students' questionnaire \\
\hline PEU & $0.924(* *)$ & $0.968(* *)$ \\
PU & $0.895(* *)$ & $0.961(* *)$ \\
ATT & $0.863(* *)$ & $0.942(* *)$ \\
BI & $0.933(* *)$ & $0.974(* *)$ \\
\hline
\end{tabular}

** Correlation is significant at the 0.01 level (2-tailed).

Table 2 shows that all the correlation coefficients among the dimensions and the total score of each questionnaire are statistically significant at the level of 0.01 .

\section{Results}

\subsection{Questionnaires Results}

Descriptive statistics including minimum, maximum- scores, means, and standard deviations were computed to summarize the participants' responses to the questionnaires.

Table 3. Descriptive statistics of teachers' questionnaire

\begin{tabular}{lllllll}
\hline Dimensions & No. of participants & No. of items & Min. & Max. & Mean & SD \\
\hline Total & 33 & 40 & 94.00 & 200.00 & 147.0 & 24.40 \\
PU & 33 & 10 & 24.00 & 50.00 & 37.45 & 6.78 \\
PEU & 33 & 10 & 19.00 & 50.00 & 38.9 & 6.88 \\
Attitude & 33 & 10 & 24.00 & 50.00 & 34.30 & 5.21 \\
BI & 33 & 10 & 16.00 & 50.00 & 36.33 & 8.76 \\
\hline
\end{tabular}


In Table 3, the participants' scores on the questionnaire ranged from a minimum of 94 to a maximum of 200 with a mean of 147.0 and a standard deviation of 24.40. The participants' showed high perceived usefulness towards D2L (37.45). Their perceived ease of use of D21 is also high (38. 9). Their attitude towards using D21 is relatively positive (34.30). They had well behavioral intentions towards using D21 in their English language teaching.

Table 4. Descriptive Statistics of students' questionnaire

\begin{tabular}{lllllll}
\hline Dimensions & No. of participants & No. of items & Min. & Max. & Mean & SD \\
\hline Total & 240 & 40 & 66.00 & 200.00 & 145.84 & 23.24 \\
PU & 240 & 10 & 13.00 & 50.00 & 37.68 & 6.42 \\
PEU & 240 & 10 & 18.00 & 50.00 & 38.10 & 6.79 \\
Attitude & 240 & 10 & 15.00 & 50.00 & 34.67 & 6.02 \\
BI & 240 & 10 & 14.00 & 50.00 & 35.36 & 7.55 \\
\hline
\end{tabular}

As shown in Table 4, students' scores on the questionnaire ranged from a minimum of 66 to a maximum of 200 with a mean of 145.8 and a standard deviation of 23.24. Results revealed that the students had high perceived usefulness towards D2L (37.68). Their perceived ease of use of D21 is also high (38.10). Their attitude towards using D21 is relatively positive (34.67).

The frequency of each item of the questionnaires was counted and presented in percentages. Weighted means and SD were also computed. The choices for each Likert scale statement in the questionnaires were combined and presented to get a comprehensive view of students and teachers' perceptions and attitudes towards integrating D2L in teaching and learning English.

Tables $5,6,7, \& 8$ show the frequency data of teachers' opinions for each statement of the four dimensions of the questionnaire. They also represent means, standard deviations and the result for each one.

For the first research question of the study, Table 5 represents data for teachers' perceived usefulness of D2L use.

Table 5. The frequency of teachers' responses, means and standard deviations for perceived usefulness (PU)

\begin{tabular}{|c|c|c|c|c|c|c|c|c|}
\hline $\begin{array}{l}\text { First dimension items } \\
\text { (PU) }\end{array}$ & $\begin{array}{l}\text { Strongly } \\
\text { agree }\end{array}$ & Agree & Neutral & Disagree & $\begin{array}{l}\text { Strongly } \\
\text { disagree }\end{array}$ & Mean & SD & Result \\
\hline $\begin{array}{l}\text { 1. Using D2L improves my EFL } \\
\text { teaching performance. }\end{array}$ & $\begin{array}{l}8 \\
\% 24.2\end{array}$ & $\begin{array}{l}17 \\
\% 51.5\end{array}$ & $\begin{array}{ll}2 \\
6.1 \%\end{array}$ & $\begin{array}{l}5 \\
\% 15.2\end{array}$ & $\begin{array}{l}1 \\
3 \%\end{array}$ & 3.7 & 1.0 & Agree \\
\hline 2. $\mathrm{D} 2 \mathrm{~L}$ is useful. & $\begin{array}{l}13 \\
\% 39.4\end{array}$ & $\begin{array}{l}17 \\
\% 15.5\end{array}$ & $\begin{array}{l}2 \\
6.1 \%\end{array}$ & $\begin{array}{l}1 \\
3 \%\end{array}$ & $\begin{array}{l}0 \\
0 \%\end{array}$ & 4.2 & .71 & $\begin{array}{l}\text { Strongly } \\
\text { Agree }\end{array}$ \\
\hline $\begin{array}{l}\text { 3. D2L improves my students' } \\
\text { participation and activities. }\end{array}$ & $\begin{array}{l}4 \\
12.1 \%\end{array}$ & $\begin{array}{l}20 \\
\% 60.6\end{array}$ & $\begin{array}{l}6 \\
\% 18.2\end{array}$ & $\begin{array}{l}2 \\
6.1 \%\end{array}$ & $\begin{array}{l}1 \\
3 \%\end{array}$ & 3.7 & .87 & Agree \\
\hline $\begin{array}{l}\text { 4. D2L develops my academic } \\
\text { skills. }\end{array}$ & $\begin{array}{l}3 \\
9.1 \%\end{array}$ & $\begin{array}{l}15 \\
45.5 \%\end{array}$ & $\begin{array}{l}6 \\
\% 18.2\end{array}$ & $\begin{array}{l}7 \\
21.2 \%\end{array}$ & $\begin{array}{l}2 \\
6.1 \%\end{array}$ & 3.3 & 1.1 & Agree \\
\hline $\begin{array}{l}\text { 5. Using D2L improves my } \\
\text { students' achievement. }\end{array}$ & $\begin{array}{l}4 \\
12.1 \%\end{array}$ & $\begin{array}{l}16 \\
\% 48.5\end{array}$ & $\begin{array}{l}9 \\
\% 27.3\end{array}$ & $\begin{array}{l}4 \\
\% 12.1\end{array}$ & $\begin{array}{l}0 \\
0 \%\end{array}$ & 3.6 & .86 & Agree \\
\hline $\begin{array}{l}\text { 6. Integrating D2L in teaching } \\
\text { English develops my abilities to } \\
\text { use computer. }\end{array}$ & $\begin{array}{l}9 \\
27.3 \%\end{array}$ & $\begin{array}{l}17 \\
51.5 \%\end{array}$ & $\begin{array}{l}3 \\
9.1 \%\end{array}$ & $\begin{array}{l}4 \\
12.1 \%\end{array}$ & $\begin{array}{l}0 \\
0 \%\end{array}$ & 3.9 & .93 & Agree \\
\hline $\begin{array}{l}\text { 7. Integrating D2L decreases time } \\
\text { for teaching and examination. }\end{array}$ & $\begin{array}{l}4 \\
12.1 \%\end{array}$ & $\begin{array}{l}15 \\
45.5 \%\end{array}$ & $\begin{array}{l}4 \\
12.1 \%\end{array}$ & $\begin{array}{l}8 \\
24.2 \%\end{array}$ & $\begin{array}{l}2 \\
6.1 \%\end{array}$ & 3.3 & 1.1 & Agree \\
\hline $\begin{array}{l}\text { 8. D2L videos attract students' } \\
\text { attention. }\end{array}$ & $\begin{array}{l}7 \\
21.2 \%\end{array}$ & $\begin{array}{l}18 \\
54.5 \%\end{array}$ & $\begin{array}{l}6 \\
18.2 \%\end{array}$ & $\begin{array}{l}2 \\
6.1 \%\end{array}$ & $\begin{array}{l}0 \\
0 \%\end{array}$ & 3.9 & .80 & Agree \\
\hline $\begin{array}{l}\text { 9. D2L improves my evaluation } \\
\text { techniques. }\end{array}$ & $\begin{array}{l}5 \\
15.2 \%\end{array}$ & $\begin{array}{l}22 \\
66.7 \%\end{array}$ & $\begin{array}{l}4 \\
12.1 \%\end{array}$ & $\begin{array}{l}1 \\
3 \%\end{array}$ & $\begin{array}{l}1 \\
3 \%\end{array}$ & 3.8 & .81 & Agree \\
\hline
\end{tabular}




virtual room increases students' $15.2 \% \quad 51.5 \% \quad 21.2 \% \quad 12.1 \% \quad 0 \%$
involvement.

Note. The percentages appear below the frequencies.

Results of Table 5 showed that the teachers responded favorably to all the statements of the first construct of the questionnaire. They agreed on all the statements and strongly agreed on the second item.

As for the first research question, Table 6 represents teachers' responses towards the perceived ease of use of $\mathrm{D} 2 \mathrm{~L}$ in their teaching process.

Table 6. The frequency of teachers' responses, means and standard deviations for Perceived ease of use (PEU)

\begin{tabular}{lllr}
\hline $\begin{array}{l}\text { Second dimension } \\
(\mathrm{PEU})\end{array}$ & $\begin{array}{l}\text { Strongly } \\
\text { agree }\end{array}$ & Agree Neutral Disagree $\begin{array}{l}\text { Strongly } \\
\text { disagree }\end{array}$ & Mean SD Result \\
\hline
\end{tabular}

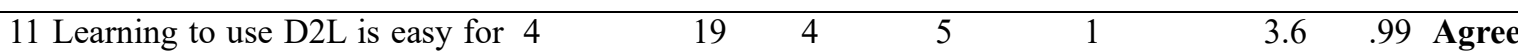
me.

$12.1 \%$

12 It is easy to access, sending, and 10 receiving EL teaching materials $30.3 \%$ through D2L.

13 My interaction with D2L is 6 clear.

14 Using D2L toolbar is obvious. $\quad 10$

$$
30.3 \%
$$

15 Setting up D21 virtual room is 3 an easy way for interacting with $9.1 \%$ students anywhere and anytime.

16 It is easy to form groups of 6 students through D2L tools.

17 Access to D2L material store 6 (LOR) is easy.

$$
18.2 \%
$$

18 Using D21 rubric tool is not 5 difficult.

$19 \mathrm{D} 2 \mathrm{~L}$ news tool is a quick option 16 for announcing dates of exams, $48.5 \%$ grades, and workshops.

20 D2L dropbox tool facilitate 13 submitting assignments.

$\begin{array}{llll}57.6 \% & 12.1 \% & 15.2 \% & 3 \% \\ 16 & 3 & 2 & 2 \\ 48.5 \% & 9.1 \% & 6.1 \% & 6.1 \%\end{array}$

$\begin{array}{llll}22 & 3 & 1 & 1\end{array}$
$66.7 \% 9.1 \% \quad 3 \% \quad 3 \%$

$\begin{array}{lllllll}19 & 1 & 1 & 2 & 4.0 & 1.0 & \text { Agree } \\ 57.6 \% & 3 \% & 3 \% & 6.1 \% & & & \end{array}$

$\begin{array}{clllll}57.6 \% & 3 \% & 3 \% & 6.1 \% & & \\ 21 & 6 & 2 & 1 & 3.6 & .84 \text { Agree } \\ 63.6 \% & 18.2 \% & 6.1 \% & 3 \% & & \end{array}$

$\begin{array}{lllllll}19 & 6 & 2 & 0 & 3.8 & .78 \text { Agree } \\ 57.6 \% & 18.2 \% & 6.1 \% & 0 \% & & & \end{array}$

$\begin{array}{llll}18 & 5 & 4 & 0\end{array}$

\section{$\begin{array}{lll}3.7 & .89 & \text { Agree }\end{array}$} $54.5 \% \quad 15.2 \% \quad 12.1 \% \quad 0 \%$

$\begin{array}{lllllll}16 & 8 & 3 & 1 & 3.6 & .96 & \text { Agree }\end{array}$

$\begin{array}{lllllll}15 & 2 & 3 & 0 & 4.1 & .90 & \text { Agree }\end{array}$

Note. The percentages appear below the frequencies.

Results of Table 6 indicated that the teachers positively agreed on D2L ease of use. They agreed on the statements that represented D2L perceived ease of use. Moreover, $(48.5 \%)$ of them strongly agreed that the D2L news tool is a quick option for announcing dates of exams, grades, and workshops.

Table 7 represents answers for the second research question which examines teachers' attitudes towards integrating D2L in their EFL teaching process. 
Table 7. The frequency of teachers' responses, means and standard deviations for Attitudes towards D2L use (ATTD2L)

\begin{tabular}{|c|c|c|c|c|c|c|c|c|}
\hline $\begin{array}{l}\text { Third dimension } \\
\text { (ATTD2L) }\end{array}$ & $\begin{array}{l}\text { Strongly } \\
\text { agree }\end{array}$ & Agree & Neutral & Disagree & $\begin{array}{l}\text { Strongly } \\
\text { disagree }\end{array}$ & Mean & SD & Result \\
\hline $\begin{array}{l}21 \text { Using D2L makes EL teaching } \\
\text { interesting. }\end{array}$ & $\begin{array}{l}6 \\
18.2 \%\end{array}$ & $\begin{array}{l}19 \\
57.5 \%\end{array}$ & $\begin{array}{l}3 \\
9.1 \%\end{array}$ & $\begin{array}{l}4 \\
12.1 \%\end{array}$ & $\begin{array}{l}1 \\
3 \%\end{array}$ & 3.7 & 1.0 & Agree \\
\hline $\begin{array}{l}22 \text { It is a good idea to use } \mathrm{D} 2 \mathrm{~L} \text { in } \\
\text { my EL courses. }\end{array}$ & $\begin{array}{l}8 \\
30.3 \%\end{array}$ & $\begin{array}{l}18 \\
48.5 \%\end{array}$ & $\begin{array}{l}5 \\
9.1 \%\end{array}$ & $\begin{array}{l}1 \\
6.1 \%\end{array}$ & $\begin{array}{l}1 \\
6.1 \%\end{array}$ & 3.9 & .89 & Agree \\
\hline $\begin{array}{l}23 \text { Using D2L gives me more } \\
\text { experience } \\
\text { performance. }\end{array}$ & $\begin{array}{l}6 \\
18.2 \%\end{array}$ & $\begin{array}{l}19 \\
57.6 \%\end{array}$ & $\begin{array}{l}2 \\
6.1 \%\end{array}$ & $\begin{array}{l}3 \\
9.1 \%\end{array}$ & $\begin{array}{l}3 \\
9.1 \%\end{array}$ & 3.6 & 1.2 & Agree \\
\hline $\begin{array}{l}24 \text { Using D2L makes me feel } \\
\text { comfortable in my teaching } \\
\text { practices. }\end{array}$ & $\begin{array}{l}7 \\
21.2 \%\end{array}$ & $\begin{array}{l}15 \\
45.5 \%\end{array}$ & $\begin{array}{l}8 \\
24.2 \%\end{array}$ & $\begin{array}{l}1 \\
3 \%\end{array}$ & $\begin{array}{l}2 \\
6.1 \%\end{array}$ & 3.7 & 1.0 & Agree \\
\hline $\begin{array}{l}25 \mathrm{D} 2 \mathrm{~L} \text { has valuable tools that } \\
\text { make English courses beneficial. }\end{array}$ & $\begin{array}{l}7 \\
12.2 \%\end{array}$ & $\begin{array}{l}18 \\
54.5 \%\end{array}$ & $\begin{array}{l}5 \\
15.2 \%\end{array}$ & $\begin{array}{l}2 \\
56.1 \%\end{array}$ & $\begin{array}{l}1 \\
3 \%\end{array}$ & 3.8 & .93 & Agree \\
\hline $\begin{array}{l}26 \text { D2L improves the quality of } \\
\text { English language learning } \\
\text { outcomes. }\end{array}$ & $\begin{array}{l}5 \\
15.2 \%\end{array}$ & $\begin{array}{l}15 \\
45.5 \%\end{array}$ & $\begin{array}{l}10 \\
30.3 \%\end{array}$ & $\begin{array}{l}1 \\
3 \%\end{array}$ & $\begin{array}{l}2 \\
6.1 \%\end{array}$ & 3.6 & .96 & Agree \\
\hline $\begin{array}{l}27 \text { There is no use for integrating } \\
\text { D2L in my teaching process. }\end{array}$ & $\begin{array}{l}4 \\
12.1 \%\end{array}$ & $\begin{array}{l}7 \\
21.2 \%\end{array}$ & $\begin{array}{l}5 \\
15.2 \%\end{array}$ & $\begin{array}{l}13 \\
39.4 \%\end{array}$ & $\begin{array}{l}4 \\
12.1 \%\end{array}$ & 2. 8 & 1.2 & Disagree \\
\hline $\begin{array}{l}28 \text { I dislike the idea of integrating } \\
\text { D2L in my EL courses. }\end{array}$ & $\begin{array}{l}3 \\
9.1 \%\end{array}$ & $\begin{array}{l}3 \\
9.1 \%\end{array}$ & $\begin{array}{l}5 \\
15.2 \%\end{array}$ & $\begin{array}{l}18 \\
54.5 \%\end{array}$ & $\begin{array}{l}4 \\
12.1 \%\end{array}$ & 2.6 & 1.1 & Disagree \\
\hline $\begin{array}{l}29 \text { I prefer that I did not have to } \\
\text { use D2L for my English language } \\
\text { courses. }\end{array}$ & $\begin{array}{l}3 \\
9.1 \%\end{array}$ & $\begin{array}{l}5 \\
15.2 \%\end{array}$ & $\begin{array}{l}4 \\
12.1 \%\end{array}$ & $\begin{array}{l}19 \\
57.6 \%\end{array}$ & $\begin{array}{l}2 \\
6.1 \%\end{array}$ & 2.6 & 1.1 & Disagree \\
\hline $\begin{array}{l}30 \text { Using D21 makes teaching } \\
\text { English enjoyable. }\end{array}$ & $\begin{array}{l}6 \\
18.2 \%\end{array}$ & $\begin{array}{l}16 \\
485 \%\end{array}$ & $\begin{array}{l}8 \\
24.2 \%\end{array}$ & $\begin{array}{l}1 \\
3 \%\end{array}$ & $\begin{array}{l}2 \\
6.1 \%\end{array}$ & 3.6 & 1.0 & Agree \\
\hline
\end{tabular}

Note. The percentages appear below the frequencies.

Results of Table 7 showed teachers' positive attitudes towards using D2L. The negative items also revealed their positive attitudes, for instance, $39.4 \%$ disagreed that there was no use for integrating D2L in their teaching process. $54.5 \%$ of the participants disagreed that they disliked the idea of integrating D2L in their EL courses. $57.6 \%$ of the teachers disagreed that they preferred that they did not have to use D2L in their English language courses.

As for the second question, Table 8 shows the frequency data of teachers' behavioral intentions towards integrating and using D2L in their teaching process.

Table 8. The frequency of teachers' responses, means and standard deviations for Behavioral Intention (BI)

\begin{tabular}{|c|c|c|c|c|c|c|c|c|}
\hline $\begin{array}{l}\text { Fourth dimension } \\
\text { (BI) }\end{array}$ & $\begin{array}{l}\text { Strongly } \\
\text { agree }\end{array}$ & Agree & Neutral & Disagree & $\begin{array}{l}\text { Strongly } \\
\text { disagree }\end{array}$ & Mean & SD & Result \\
\hline $\begin{array}{l}\text { 31 Whenever possible, I would intend } \\
\text { to use D2L for English language } \\
\text { classes. }\end{array}$ & $\begin{array}{l}6 \\
18.2 \%\end{array}$ & $\begin{array}{l}15 \\
45.5 \%\end{array}$ & $\begin{array}{l}7 \\
21.2 \%\end{array}$ & $\begin{array}{l}4 \\
12.1 \%\end{array}$ & $\begin{array}{l}1 \\
3 \%\end{array}$ & 3.6 & 1.0 & Agree \\
\hline $\begin{array}{l}32 \text { I would plan to integrate D2L } \\
\text { exam and grading tools in all my El } \\
\text { courses. }\end{array}$ & $\begin{array}{l}4 \\
12.1 \%\end{array}$ & $\begin{array}{l}14 \\
42.4 \%\end{array}$ & $\begin{array}{l}10 \\
30.3 \%\end{array}$ & $\begin{array}{l}3 \\
9.1 \%\end{array}$ & $\begin{array}{l}2 \\
6.1 \%\end{array}$ & 3.4 & 1.0 & Agree \\
\hline 33 I would intend to use $\mathrm{D} 2 \mathrm{~L}$ & 4 & 16 & 7 & 4 & 2 & 3.4 & 1.0 & Agree \\
\hline
\end{tabular}


discussion and forum tools in the $12.1 \% \quad 48.5 \% \quad 21.2 \% \quad 12.1 \% \quad 6.1 \%$

future.

34 I would recommend using D2L 5

tools in EL teaching to my colleagues. $15.2 \%$

35 I would motivate my students to 6

$\log$ in and make use of D2L options. $\quad 18.2 \%$

36 I would like to use D2L for 6

distance teaching from home.

$18.2 \%$

37 I would intend to learn more about 10

D2L uses and options in English 30.3\%

language teaching.

38 I would like to be able to use D2L 6

as a replacement for some EFL $18.2 \%$

teaching practices.

39 I would intend to use D2L dropobx 17

for receiving students' assignments.

$51.5 \%$

$\begin{array}{llll}16 & 5 & 5 & 2\end{array}$

2

$3.5 \quad 1.1$ Agree

$48.5 \% \quad 15.2 \% \quad 15.2 \% \quad 6.1 \%$

$\begin{array}{llll}18 & 5 & 2 & 2\end{array}$

$54.5 \% \quad 15.2 \% \quad 6.1 \% \quad 6.1 \%$

$\begin{array}{llllll}16 & 4 & 4 & 3 & 3.5 & 1.2\end{array}$

$48.5 \% \quad 12.1 \% \quad 12.1 \% \quad 9.1 \%$

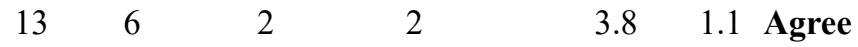

$39.4 \% \quad 18.2 \% \quad 6.1 \% \quad 6.1 \%$

$\begin{array}{lllllll}12 & 5 & 7 & 3 & 3.3 & 1.2 & \text { Agree }\end{array}$

$36.4 \% \quad 15.2 \% \quad 21.2 \% \quad 9.1 \%$

40 I would intend to upload my 17

course materials to D2L content tool. $\quad 51.5 \%$

$\begin{array}{lll}8 & 5 & 3\end{array}$

0

3.9

88 Agree

$24.2 \% \quad 15.2 \% \quad 9.1 \% \quad 0 \%$

$\begin{array}{lllllll}9 & 3 & 4 & 0 & 3.9 & .88 & \text { Agree }\end{array}$

Note. The percentages appear below the frequencies.

Results of Table 8 indicated that the participants had positive behavioral intentions towards integrating D2L in their English teaching process. They agreed with all the statements that showed their behavioral intentions of using D2L.

Tables 9, 10, 11, \& 12 show the frequency data of the students' opinions for each statement of the four dimensions of the students' questionnaire. They also represent means, standard deviations and the result for each one.

Table 9. The frequency of students' responses, means and standard deviations for Perceived usefulness (PU)

\begin{tabular}{llll}
\hline $\begin{array}{l}\text { First dimension items } \\
\text { (PU) }\end{array}$ & $\begin{array}{l}\text { Strongly } \\
\text { agree }\end{array}$ & Agree Neutral Disagree Strongly & $\begin{array}{c}\text { Mean SD Result } \\
\text { disagree }\end{array}$ \\
\hline
\end{tabular}

\begin{tabular}{|c|c|c|c|c|c|c|c|c|}
\hline 1. D2L supports my English language & 38 & 131 & 47 & 18 & 6 & 3.7 & .90 & Agree \\
\hline learning process. & $15.8 \%$ & 33 & $19.6 \%$ & $7.5 \%$ & $2.5 \%$ & & & \\
\hline 2. D2L enhances my English language & 37 & 117 & 63 & 20 & 3 & 3.6 & .87 & Agree \\
\hline achievement. & $15.4 \%$ & 34 & $26.3 \%$ & $8.3 \%$ & $1.2 \%$ & & & \\
\hline 3. D21 survey tool enables me to & 38 & 111 & 70 & 20 & 1 & 3.6 & .85 & Agree \\
\hline $\begin{array}{l}\text { express my opinions about the quality } \\
\text { of my English language courses. }\end{array}$ & $15.8 \%$ & $46.3 \%$ & $29.2 \%$ & $8.3 \%$ & $0.4 \%$ & & & \\
\hline 4. D2L increases interaction with my & 46 & 117 & 58 & 16 & 3 & 3.7 & .87 & Agree \\
\hline $\begin{array}{l}\text { EL teachers and classmates through } \\
\text { discussion and forum tools. }\end{array}$ & $19.2 \%$ & $48.8 \%$ & $24.2 \%$ & $6.7 \%$ & $1.2 \%$ & & & \\
\hline 5. D2L news tool keeps me updated & 60 & 116 & 41 & 10 & 6 & 3.8 & .91 & Agree \\
\hline with all upcoming class events. & $25 \%$ & $48.3 \%$ & $20 \%$ & $4.2 \%$ & $2.5 \%$ & & & \\
\hline 6. D2L helps me to access the contents & 51 & 133 & 41 & 12 & 3 & 3.9 & .83 & Agree \\
\hline and quizzes of my EL courses. & $21.3 \%$ & $55.4 \%$ & $17.1 \%$ & $5 \%$ & $1.2 \%$ & & & \\
\hline 7. D2L dropbox is a useful tool for & 65 & 102 & 57 & 11 & 5 & 3.8 & .93 & Agree \\
\hline submitt & $27.1 \%$ & $42.5 \%$ & $23.8 \%$ & $4.6 \%$ & $2.1 \%$ & & & \\
\hline 8. D2L motivates me to participate in & 23 & 107 & 72 & 21 & 8 & 3.5 & .94 & Agree \\
\hline
\end{tabular}




\begin{tabular}{llllllllll}
\hline class groups. & $13.3 \%$ & $44.6 \%$ & $30 \%$ & $8.8 \%$ & $3.3 \%$ & & \\
9. D2L improves my EFL study skills. & 54 & 112 & 65 & 13 & 5 & 3.8 & .91 & Agree \\
& & $22.5 \%$ & $46.7 \%$ & $23.3 \%$ & $5.4 \%$ & $2.1 \%$ & & & \\
10. D2L develops my & English & 45 & 117 & 54 & 19 & 5 & 3.7 & .92 & Agree \\
language academic skills. & $18.8 \%$ & $48.8 \%$ & $22.5 \%$ & $7.9 \%$ & $2.1 \%$ & & &
\end{tabular}

Note. The percentages appear below the frequencies.

Table 9 represents answers to the third research question which explores students' perception towards using D2L in their English learning process. The ten statements investigated their perceived usefulness of D2L. Results indicated their agreements on D2L perceived usefulness.

Table 10. The frequency of students' responses, means and standard deviations for perceived ease of use (PEU)

\begin{tabular}{|c|c|c|c|c|c|c|c|c|}
\hline $\begin{array}{l}\text { Second dimension } \\
\text { (PEU) }\end{array}$ & $\begin{array}{l}\text { Strongly } \\
\text { agree }\end{array}$ & Agree & Neutral & Disagree & $\begin{array}{l}\text { Strongly } \\
\text { disagree }\end{array}$ & Mean & SD & Result \\
\hline \multirow{2}{*}{$\begin{array}{l}11 \text { Using D2L toolbar is clear and } \\
\text { understandable. }\end{array}$} & 65 & 122 & 40 & 12 & 1 & \multirow[t]{2}{*}{3.9} & \multirow[t]{2}{*}{.82} & \multirow[t]{2}{*}{ Agree } \\
\hline & & $50.8 \%$ & $16.7 \%$ & $5 \%$ & $0.4 \%$ & & & \\
\hline \multirow{2}{*}{$\begin{array}{l}12 \text { D2L makes it easy for me to access } \\
\text { quickly to EL course contents and } \\
\text { homework }\end{array}$} & 67 & 110 & 48 & 11 & 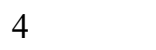 & \multirow[t]{2}{*}{3.9} & \multirow[t]{2}{*}{.90} & \multirow[t]{2}{*}{ Agree } \\
\hline & & $\% 45.8$ & $20 \%$ & $4.6 \%$ & 0 & & & \\
\hline \multirow{2}{*}{$\begin{array}{l}13 \text { Learning through D2L is easy for } \\
\text { me. }\end{array}$} & 60 & 101 & 55 & 13 & & \multirow[t]{2}{*}{3.7} & \multirow[t]{2}{*}{1.0} & \multirow[t]{2}{*}{ Agree } \\
\hline & $25^{\circ}$ & $\% 42.1$ & 22. & $5.4 \%$ & 4.6 & & & \\
\hline \multirow{2}{*}{$\begin{array}{l}14 \text { D2L makes it easy for me to } \\
\text { receive quickly EL learning materials. }\end{array}$} & 51 & 144 & 56 & 13 & 6 & \multirow[t]{2}{*}{3.7} & \multirow[t]{2}{*}{.92} & \multirow[t]{2}{*}{ Agree } \\
\hline & $\% 2$ & $\% 47.5$ & $\% 2$ & $5.4 \%$ & $2.5 \%$ & & & \\
\hline \multirow{2}{*}{$\begin{array}{l}15 \text { Taking exams and quizzes is an } \\
\text { easy process through D2L. }\end{array}$} & 54 & 118 & 49 & 15 & 4 & \multirow[t]{2}{*}{3.8} & \multirow[t]{2}{*}{.89} & \multirow[t]{2}{*}{ Agree } \\
\hline & $\% 22.5$ & $\% 49.2$ & $\% 20.4$ & $6.3 \%$ & $1.7 \%$ & & & \\
\hline \multirow{2}{*}{$\begin{array}{l}16 \text { Instructions for using D2L are } \\
\text { obvious to me. }\end{array}$} & 46 & 119 & 45 & 17 & 4 & \multirow[t]{2}{*}{3.7} & \multirow[t]{2}{*}{.89} & \multirow[t]{2}{*}{ Agree } \\
\hline & $\% 19.2$ & $\% 49.6$ & $\% 22.5$ & $7.1 \%$ & $1.7 \%$ & & & \\
\hline \multirow{2}{*}{$\begin{array}{l}17 \text { D2L dropbox makes the } \\
\text { submission of assignments easy. }\end{array}$} & 53 & 112 & 57 & 15 & 3 & \multirow[t]{2}{*}{3.8} & \multirow[t]{2}{*}{.88} & \multirow[t]{2}{*}{ Agree } \\
\hline & 22.1 & $46.6 \%$ & $23.8 \%$ & $6.3^{\circ}$ & 1.2 & & & \\
\hline \multirow{2}{*}{$\begin{array}{l}18 \text { It is easy to interact with my } \\
\text { teachers through D2L }\end{array}$} & 44 & 112 & 56 & 23 & 5 & \multirow[t]{2}{*}{3.6} & \multirow[t]{2}{*}{.94} & \multirow[t]{2}{*}{ Agree } \\
\hline & & $446.7 \%$ & $23.3 \%$ & $9.6 \%$ & 2.1 & & & \\
\hline \multirow{2}{*}{$\begin{array}{l}19 \text { D2L helps me to join groups of my } \\
\text { classmates easily }\end{array}$} & 37 & 115 & 67 & 18 & 3 & \multirow[t]{2}{*}{3.6} & .86 & Agree \\
\hline & & $\% 47.9$ & $\% 27.9$ & $7.5 \%$ & & & & \\
\hline 20 The D2L news is an instant and & 48 & 118 & 53 & 16 & 5 & 3.7 & .91 & Agree \\
\hline $\begin{array}{l}\text { quick tool for keeping me updated } \\
\text { with schedule, exams, meeting, and } \\
\text { workshops. }\end{array}$ & $\% 2$ & $\% 49.2$ & $\% 22.1$ & $6.7 \%$ & 2.1 & & & \\
\hline
\end{tabular}

Note. The percentages appear below the frequencies.

Table 10 represents students' responses on perceived ease of use of D2L. The participants agreed with the statements of this dimension of the questionnaire. Therefore, results showed that they considered D2L easy to use.

Table 11. The frequency of students' responses, means and standard deviations for Attitudes towards D2L use (ATTD2L)

\begin{tabular}{llrl}
\hline Third dimension (ATTD2L) & $\begin{array}{l}\text { Strongly } \\
\text { agree }\end{array}$ & Agree Neutral Disagree $\begin{array}{l}\text { Strongly } \\
\text { disagree }\end{array}$ & Mean SD Result \\
\hline
\end{tabular}




\begin{tabular}{|c|c|c|c|c|c|c|c|c|}
\hline \multirow{2}{*}{$\begin{array}{l}21 \text { Using D2L makes EL learning } \\
\text { interesting. }\end{array}$} & 51 & 112 & 50 & 21 & 6 & \multirow[t]{2}{*}{3.7} & \multirow{2}{*}{\multicolumn{2}{|c|}{.96 Agree }} \\
\hline & $21.3 \%$ & $46.7 \%$ & $20.8 \%$ & $8.8 \%$ & $2.5 \%$ & & & \\
\hline \multirow{2}{*}{$\begin{array}{l}22 \text { It is a good idea to use } D 2 L \text { in } \\
\text { my EL course. }\end{array}$} & 42 & 125 & 52 & 19 & 2 & \multirow[t]{2}{*}{3.7} & \multirow[t]{2}{*}{.85} & \multirow[t]{2}{*}{ Agree } \\
\hline & $17.5 \%$ & $52.1 \%$ & $21.7 \%$ & $7.9 \%$ & $0.8 \%$ & & & \\
\hline \multirow{2}{*}{$\begin{array}{l}23 \text { D2L helps me to increase my } \\
\text { creativity in English language } \\
\text { courses. }\end{array}$} & 35 & 119 & 57 & 26 & 3 & \multirow[t]{2}{*}{3.6} & \multirow[t]{2}{*}{.90} & \multirow[t]{2}{*}{ Agree } \\
\hline & $14.6 \%$ & $49.6 \%$ & $23.7 \%$ & $10.8 \%$ & $1.2 \%$ & & & \\
\hline \multirow{2}{*}{$\begin{array}{l}24 \text { I enjoy my English classes when } \\
\text { D2L is used. }\end{array}$} & 40 & 108 & 66 & 22 & 4 & \multirow[t]{2}{*}{3.6} & \multirow[t]{2}{*}{.91} & \multirow[t]{2}{*}{ Agree } \\
\hline & $16.7 \%$ & $45 \%$ & $27.5 \%$ & $9.2 \%$ & $1.7 \%$ & & & \\
\hline \multirow{2}{*}{$\begin{array}{l}25 \mathrm{D} 2 \mathrm{~L} \text { is more enjoyable and } \\
\text { innovative than the traditional } \\
\text { learning. }\end{array}$} & 44 & 111 & 60 & 19 & 6 & \multirow[t]{2}{*}{3.7} & \multirow[t]{2}{*}{.94} & \multirow[t]{2}{*}{ Agree } \\
\hline & $18.3 \%$ & $46.3 \%$ & $25 \%$ & $7.9 \%$ & $2.5 \%$ & & & \\
\hline \multirow{2}{*}{$\begin{array}{l}26 \text { D2L has valuable tools that } \\
\text { make English courses beneficial. }\end{array}$} & 39 & 114 & 59 & 23 & 5 & \multirow[t]{2}{*}{3.6} & \multirow[t]{2}{*}{.93} & \multirow[t]{2}{*}{ Agree } \\
\hline & $16.3 \%$ & $47.5 \%$ & $24.6 \%$ & $9.6 \%$ & $2.1 \%$ & & & \\
\hline \multirow{2}{*}{$\begin{array}{l}27 \text { I dislike the idea of integrating } \\
\text { D2L in my EL courses. }\end{array}$} & 16 & 15 & 61 & 58 & 90 & \multirow[t]{2}{*}{3.1} & \multirow[t]{2}{*}{1.0} & \multirow[t]{2}{*}{ S. disagree } \\
\hline & $6.7 \%$ & $6.3 \%$ & $25.4 \%$ & $24.2 \%$ & $37.5 \%$ & & & \\
\hline \multirow{2}{*}{$\begin{array}{l}28 \text { I prefer that I did not have to use } \\
\text { D2L in my English language } \\
\text { courses. }\end{array}$} & 16 & 16 & 72 & 51 & 85 & & \multirow[t]{2}{*}{1.0} & \multirow[t]{2}{*}{ S. disagree } \\
\hline & $6.7 \%$ & $6.7 \%$ & $30 \%$ & $21.3 \%$ & $35.4 \%$ & 3.1 & & \\
\hline \multirow{2}{*}{$\begin{array}{l}29 \text { There is no use for integrating } \\
\text { D2L in my EL learning process. }\end{array}$} & 14 & 18 & 66 & 51 & 91 & \multirow[t]{2}{*}{3.1} & \multirow[t]{2}{*}{1.0} & \multirow[t]{2}{*}{ S. disagree } \\
\hline & $5.8 \%$ & $7.5 \%$ & $27.5 \%$ & $21.3 \%$ & $37.9 \%$ & & & \\
\hline \multirow{2}{*}{$\begin{array}{l}30 \text { I am not eager to participate in } \\
\text { the D2L discussion tool with my } \\
\text { teachers and classmates. }\end{array}$} & 17 & 24 & 59 & 56 & 84 & 3.0 & 1.1 & S. .disagree \\
\hline & $7.1 \%$ & $10 \%$ & $24.6 \%$ & $23.3 \%$ & $35 \%$ & & & \\
\hline
\end{tabular}

Note. The percentages appear below the frequencies.

Table 11 represents answers to the fourth question which investigates students' attitudes towards integrating D21 in their courses. Majority of students agreed that using D2L makes EL learning interesting. They also strongly disagreed with the negative statements. Therefore, these results proved their positive attitudes towards integrating D2L in their English language learning process.

Table 12. The frequency of students' responses, means and standard deviations for Behavioral Intention (BI)

\begin{tabular}{|c|c|c|c|c|c|c|c|c|}
\hline $\begin{array}{l}\text { Fourth dimension } \\
\text { (BI) }\end{array}$ & $\begin{array}{l}\text { Strongly } \\
\text { agree }\end{array}$ & Agree & Neutral & Disagree & $\begin{array}{l}\text { Strongly } \\
\text { disagree }\end{array}$ & Mean & SD & Result \\
\hline $\begin{array}{l}\text { 31. I would intend to learn } \\
\text { more about D2L uses in } \\
\text { English language learning. }\end{array}$ & $\begin{array}{l}39 \\
16.3 \%\end{array}$ & $\begin{array}{l}105 \\
43.8 \%\end{array}$ & $\begin{array}{l}65 \\
27.1 \%\end{array}$ & $\begin{array}{l}28 \\
11.7 \%\end{array}$ & $\begin{array}{l}3 \\
1.2 \%\end{array}$ & 3.6 & .93 & Agree \\
\hline $\begin{array}{l}\text { 32. I would plan to use D2L } \\
\text { tools during my EL studying. }\end{array}$ & $\begin{array}{l}35 \\
14.6 \%\end{array}$ & $\begin{array}{l}100 \\
41.7 \%\end{array}$ & $\begin{array}{l}74 \\
30.8 \%\end{array}$ & $\begin{array}{l}25 \\
10.4 \%\end{array}$ & $\begin{array}{l}6 \\
2.5 \%\end{array}$ & 3.5 & .94 & Agree \\
\hline $\begin{array}{l}\text { 33. I would intend to use } \\
\text { D2L in my future study. }\end{array}$ & $\begin{array}{l}36 \\
15 \%\end{array}$ & $\begin{array}{l}92 \\
38.3 \%\end{array}$ & $\begin{array}{l}76 \\
31.7 \%\end{array}$ & $\begin{array}{l}27 \\
11.3 \%\end{array}$ & $\begin{array}{l}9 \\
3.7 \%\end{array}$ & 3.4 & 1.0 & Agree \\
\hline $\begin{array}{l}\text { 34. I would like to use D2L } \\
\text { for distance learning from } \\
\text { home. }\end{array}$ & $\begin{array}{l}37 \\
15.4 \%\end{array}$ & $\begin{array}{l}100 \\
41.7 \%\end{array}$ & $\begin{array}{l}63 \\
26.2 \%\end{array}$ & $\begin{array}{l}32 \\
13.3 \%\end{array}$ & $\begin{array}{l}8 \\
3.3 \%\end{array}$ & 3.5 & 1.0 & Agree \\
\hline $\begin{array}{l}\text { 35. I would encourage my } \\
\text { colleagues to use D2L tools in } \\
\text { EL learning. }\end{array}$ & $\begin{array}{l}37 \\
15.4 \%\end{array}$ & $\begin{array}{l}101 \\
42.1 \%\end{array}$ & $\begin{array}{l}70 \\
29.2 \%\end{array}$ & $\begin{array}{l}26 \\
10.8 \%\end{array}$ & $\begin{array}{l}6 \\
2.5 \%\end{array}$ & 3.5 & .96 & Agree \\
\hline
\end{tabular}




\begin{tabular}{lllllllll}
\hline $\begin{array}{l}36 . \quad \text { I would like to submit all } \\
\text { my English language }\end{array}$ & $45.8 \%$ & 99 & 63 & 29 & 4 & 3.6 & .97 & Agree \\
assignments through dropbox \\
tool.
\end{tabular}

Note. The percentages appear below the frequencies

Table 12 represents answers to the fourth question which investigates responses to students' intentions towards integrating D2L in their EFL learning process. The students showed willingness towards using D2L. Their agreements on the ten statements were in favor of using D2L in their study.

\subsection{The Interviews Results}

Tables 13, $14 \& 15$ represent the analysis of the interviews questions.

Twenty-nine teachers responded to the interview questions, and fifty students, as a representative number of the sample, were interviewed by the two authors of the study.

To verify the results gained through the questionnaires and to get a proper deep understanding of the responses, the first question of the interview asked the participants about their perception towards integrating D2L in their English language teaching or learning processes. Their responses were grouped into three themes. The frequency and the percentages are shown in Table 13.

Table 13. Participants' perception towards D21 integration in their EL classes

\begin{tabular}{llll}
\hline & Themes & Frequency & Percentage \\
\hline Teachers' interview & Perceived usefulness & 27 & $\mathbf{9 3 \%}$ \\
& Perceived ease of use & 24 & $\mathbf{8 3 \%}$ \\
& Positive attitudes & 25 & $\mathbf{8 6 \%}$ \\
Students' interview & Perceived usefulness & 40 & $\mathbf{8 0 \%}$ \\
& Perceived ease of use & 43 & $\mathbf{8 5 \%}$ \\
& Positive attitudes & 35 & $\mathbf{7 0 \%}$ \\
\hline
\end{tabular}

The second question of the interview aims at identifying the problems that may hinder the participants' use of D2L, whereas the third question represents the suggested solutions to such problems. Participants' responses to the second question were grouped into categories as shown in Table 14.

Table 14. Problems that hinder the participants' use of D2L

\begin{tabular}{llll}
\hline & Problems (Category) & Frequency & Percentage \\
\hline Teachers' responses & No difficulties or problems in D2L use & 12 & $41 \%$ \\
& Complication of use & 7 & $24 \%$ \\
\hline
\end{tabular}




\begin{tabular}{llll}
\hline & Lack of enough training in English & 5 & $17 \%$ \\
& Technical problems with Network connection & 2 & $7 \%$ \\
& Lack of students' participation & 3 & $10 \%$ \\
& Total No. of responses & 29 & \\
Students' responses & No difficulties or problems in D2L use & 30 & $60 \%$ \\
& Lack of time & 16 & $32 \%$ \\
& Internet network problems & 2 & $4 \%$ \\
& Technical problems with the system & 2 & $4 \%$ \\
Total No. of responses & 50 & \\
\hline
\end{tabular}

Results of table 14 cluster participants' responses to the fifth question of the study which seeks to identify difficulties that hinder their use of D2L. In total 29 teachers responded to this question. Twelve participants (41\%) reported that they had no problems with D2L use. On the contrary, seven participants (24\%) indicated that they consider D2L a complicated system. Five participants (17\%) said that the lack of enough training in the English language was the main reason for difficulties with their D2L use. Only two teachers (7\%) commented that their problems with D2L were technical problems with Network connection. Three participants $(10 \%)$ mentioned that the only obstacle for them was their students' lack of participation. $60 \%$ of the students pinpointed that they had no difficulties in their use of D2L. For $32 \%$ of the students, lack of time was the main problem for not using D2L. Approximately $4 \%$ of them showed that the internet network problems hindered their D2L use. $4 \%$ of them identified technical problems with the D2L system.

Table 15. Suggested solutions to the problems that hinder the participants' use of D2L

\begin{tabular}{llll}
\hline & Suggested solutions (Category) & Frequency & Percentage \\
\hline Teachers' & & & \\
responses & No suggestions & 5 & $17 \%$ \\
& System tools improvement & 4 & $14 \%$ \\
& Providing enough training in English & 12 & $41 \%$ \\
& Encouraging students' participation & 3 & $10 \%$ \\
& Strengthening the network connection & 5 & $17 \%$ \\
Students' & Total No. of responses & 29 & \\
responses & No suggestions & 20 & $40 \%$ \\
& Need more time & 10 & $20 \%$ \\
& good internet connections & 3 & $6 \%$ \\
& Use D2l inside the college & 3 & $6 \%$ \\
& Fix the technical problem of D2L system & 8 & $16 \%$ \\
& More training for D2l uses & 6 & $12 \%$ \\
& Total No. of responses & 50 & \\
\hline
\end{tabular}

Results of table 15 categorize the participants' proposed solutions to the problems that faced them in their use of the D2L system. $17 \%$ of the teachers did not give any suggestions. The vast majority of the participants reported that it is necessary to provide more training along with enough opportunities to practice $\mathrm{D} 2 \mathrm{~L}$ applications. $10 \%$ of the teachers recommended more encouragement for the students to use D2L such as allocating scores for their activation of D2L. Others (17\%) demanded good access to the internet connection within classes. $40 \%$ of the students did not suggest anything. Only $20 \%$ of the students claimed that they want more time to use D2L. $6 \%$ of them reported a request for good internet connection in the classrooms. Other students $(6 \%)$ preferred the use of D2L inside the college labs. Eight students (16\%) said that the solution to D2L difficulties is fixing its problems. $12 \%$ of them affirmed their need for additional D2L training.

\section{Discussion}

The main aims of the study focused on investigating both teachers and students' perceptions towards integrating 
the D2L system in EFL teaching and learning processes. Their perceptions were analyzed according to the four constructs of the TAM model. Moreover, it attempted to explore the problems that would hinder their use of the D2L system to suggest some relevant solutions to them.

The results of the first and third questions showed the participants' perception of D2L. The findings revealed that the majority of them had a positive perception of D2L usefulness and ease of use. This positivity supported the view of Zaza (2014) who concluded that attitude towards using blackboard system depended on how the users perceive the usefulness of technology in learning and teaching.

The data of Table 13, collected from the participants, were extremely positive towards the potentialities that D2L system offers in or out of the classroom. For example, most of the students $(40 \%)$ agreed that integrating D2L in the learning process was useful, and it eased the access to the courses' contents. One of the students commented that "if I missed a class, I would feel happy to find the lectures uploaded on D2L". This result indicates that perceived ease of use and perceived usefulness are two predictors of users' behavioral intention. This behavioral intention, in turn, determines the use of any new technology (Muller, 2013).

The students agreed that D2L ease of use motivated them to participate in discussions as well as attending online courses and workshops through D2L virtual rooms. They admitted that D2L useful tools enhanced their achievement and enabled them to get updates with upcoming class events through the news tool. For example, one student said, "it was easy and important to check my courses news through the D2L app on my mobile". They also easily accessed quizzes and submitted assignments in D2L dropbox. This result is compatible with the studies of Keller, Hrastinski and Carlsson (2007), and Teo (2006). They pointed out that perceived usefulness, and perceived ease of use influenced new technology acceptance.

This study did not only focus on teachers and students' perception towards D2L, but it also studied two significant factors, which were attitudes and behavioral intentions towards the use of D2L. According to the results of the second and fourth questions, the participants had a high positive attitude in this regard. Teachers acknowledged that D2L integration increased their experience, made them feel comfortable and changed English language courses to be more beneficial, and it improved the quality of their teaching. Therefore, they would intend to use D2L in their future classes. For instance, one of the teachers said, "I had found the question library and quizzes tools significant that I would like to use them again in all my classes." Hence, most of the teachers' responses showed positive attitudes and willingness towards using D2L. Findings of the study ascertained that teachers would intend to use D2L in their all English language classes. They would also recommend D2L to their colleagues to motivate students to log into D2L to check all its options. So, teachers' positive attitude affected their intention to use D2L. This result revealed the same conclusion of Teo (2011) who pinpointed that teachers' acceptance of technology would affect their intentions to use it.

The study put in its consideration that there might be some problems that possibly faced the participants. Table 14 shows the results of the fifth question; responses reflected some of the challenges that faced the participants during their use of D2L. Teachers assumed that anything new has its obstacles at the beginning, but one can overcome them by sufficient training. Some teachers suffered from the weak responses and interaction of few students. They attribute this to the lack of experience on how to operate D2L tools. Another reason is the negative attitude or rejection of use by some students. Many teachers had some difficulties with rubrics, grading, and competences options. These findings support Alrafi's findings (2009) that associated the success of new technology implementation to its users' beliefs.

Few responses revealed that there were some obstacles encountered by the students. Those obstacles had no relation to the system itself. For example, one of the students said, "my problem was related to time since I had to check out my portal page many times a day." Another student suggested a solution for this saying, "it would be better if teachers reduce the number of D2L assignments". Others proclaimed that the main problem was because of the corrupted internet connection which was due to their network. The results parallel Vrasidas and Class (2005) who stated that some main obstacles might occur due to the personal attitude of the users towards the easiness of operating the technology and its tools. Likewise, Alebaikan and Troudi (2010) pointed out that the adaptation of new technology could cause challenges to some students.

Most of the students who participated in this study highlighted that they did not encounter any problems when using D2L. This saying is assumed to be the result of the D2L training sessions they received. Such training opportunities facilitated their use of D2L. Therefore, adequate training and support could facilitate the use of any new technology. This finding is in line with Alebaikan and Troudi's study (2010).

As for the interviews results, students highlighted their preferences and recommendations in answer to the sixth question, Table 15. They wished to learn more about D2L tools to use them during their EFL studying. They also 
would like to use it in distance learning and encourage their colleagues to use it. They wished to have their exams through D2L. They pinpointed that D2L applications made the English language learning interesting. Therefore, they enjoyed their classes and found them more beneficial. One of the students said, "Uploading my assignments on D2L was an exciting experience for me". They wanted to leave the D2L dropbox open all the semester, and they needed a feedback icon to see the result of their homework. The findings of this study support Istifci's results (2017). In her study, she concluded that students' perceptions and recommendations are significant for developing the applications of blended learning.

Accordingly, integrating D2L in the processes of teaching and learning the English language gained acceptance among the participants of the present study. Apart from the problems they encountered, the participants' suggestions and recommendations and their implementations may be significant for educational institutions applying D2L.

\section{Conclusions}

Qualitative and quantitative data analysis indicated that teachers and students have a good perception of the D2L system. They favored it for its perceived usefulness and easiness. The results showed that they have positive attitudes and willingness towards D2L use in the future. Hence, the D2L system is an excellent tool in EFL teaching and learning process. Curriculum planner should assign activities that require D2L use to help students be autonomous learners. In the meanwhile, D2L designers should take into account the simplicity of the options and icons. Adequate training must be provided to teachers and learners to make good use of the system and to avoid potential technical problems.

This study was limited to participants at English language department, and their perception of D2L was examined in the light of the TAM model four constructs namely, perceived usefulness, perceived ease of use, attitudes, and behavioral intentions.

Further studies are needed to investigate the cognitive and metacognitive factors that affect students' perceptions and acceptance of the D2L system. It is suggested to conduct experimental studies that examine the effectiveness of using D2L in improving students' English language skills. Moreover, other survey studies may explore the factors that motivate students and teachers to use the D2L system. Studies that consider gender differences could also compare male and female perceptions and attitudes towards using the D2L system in EFL learning and teaching processes. Furthermore, correlational studies may study students' D2L perception and their EFL achievements.

\section{References}

Alrafi, A. (2009). Information systems adoption: A study of the technology acceptance model. Germany. VDM Publishing.

Alebaikan, R., \& Troudi, S. (2010). Blended learning in Saudi universities: Challenges and Perspectives. ALT-J. Research in Learning Technology, 18(1), 49-59. https://doi.org/10.1080/09687761003657614

Chen, R. (2010). Investigating Models for Preservice Teachers' Use of Technology to Support Student-Centered Learning. Computer and education, 55, 32-42. https://doi.org/10.1016/j.compedu.2009.11.015

Davis, F. D. (1989). Perceived Usefulness, Perceived Ease of Use, and User Acceptance of Information Technology. MIS Quarterly 13(3), 319-340. https://doi.org/10.2307/249008

Davis, G. B., \& Davis, F. D. (2003). User Acceptance of Information Technology: Toward a Unified View. MIS Quarterly, 27(3), 425-478 .https://doi.org/10.2307/30036540

Fahrni, P., Rudolph, J., \& De Schutter, A. (2004). Technical Evaluation Report 30. Vendor-Assisted Evaluation of a Learning Management System. International Review of Research in Open and Distance Learning, 5(1), 1-4. https://doi.org/10.19173/irrodl.v5i1.162

Istifci, I. (2017). Perceptions of Turkish EFL Students on Online Language Learning Platforms and Blended Language Learning. Journal of Education and Learning, 6(1), 113-121. https://doi.org/10.5539/jel.v6n1p113

Keller, C., Hrastinski, S., \& Carlsson, S. (2007). Students' Acceptance of E-Learning Environments: A Comparative Study in Sweden and Lithuania. Educational Technology \& Society, 14(2), 224-235.

Kitchener, W., O., \& Orlando, Fl. (2008). Desire2Learn Supports Educators Striving to Enhance Student Learning Outcomes D2L. $\quad$ Retrieved from https://www.d21.com/newsroom/releases/desire2learn-supports-educators-striving-to-enhance-student-learni 
ng-outcomes

Ku, C. (2009). Extending the Technology Acceptance Model using perceived user resources in Higher education web- based on-line learning course (Doctoral dissertation, College of Education, University of Central Florida).

Kung-Teck, W., Rosma, O., Pauline, G., \& Mohd, R. (2013). Understanding Student Teachers' Behavioural Intention to Use Technology: Technology Acceptance Model (TAM) Validation and Testing. International Journal of Instruction, 6(1), 89-104.

Muller, D. (2013). Design characteristics of virtual learning environments: A theoretical integration and empirical test of the Technology Acceptance and IS success research. (E-book). https://doi.org10.1007/978-3-658-00392-0

Nunnally, J. C. (1978). Psychometric Theory. New York: McGraw Hill.

Palloff, R., \& Pratt, K. (2013). Lessons from the virtual classroom: The realities of online teaching. Oxford: John Wiley \& Sons.

Park. S. Y. (2009). An Analysis of The Technology Acceptance Model in Understanding University Students' Behavioral Intention to use e-Learning. Educational Technology \& Society, 12(3), 150-162.

Pina, A. (2013). Learning Management System: A look at the big picture. In Y. Kats (Ed.), learning management systems and instructional design best practices in online education (pp. 1-19). USA: IGI global. https://doi.org/10.4018/978-1-4666-3930-0.ch001

Quickstart. D2L Guide (2012). Retrieved from https://learn.bcit.ca/shared/documents/D2L-quickstart-guide.pdf

Sarfraz, S., Mansoor, Z., \& Tariq, R. (2015). Teachers' and Students' Perceptions of the Communicative Language Teaching Methodology in the CALL Environment: A Case Study. Procedia - Social and Behavioral Sciences, 199, 730-736. https://doi.org/10.1016/j.sbspro.2015.07.604

Sheng, S. L. (2008). Investigating Students' Perceived Satisfaction, Behavioral Intention, and Effectiveness of E-learning: A Case Study of the Blackboard System. Computers \& Education, 51(2), 864-873. https://doi.org/10.1016/j.compedu.2007.09.005

Tello, S., \& Motiwalla, L. (2010). Using learning management system to facilitate learning outcomes assessment. In Y. Kats (Ed.), learning management systems and instructional design best practices in online education (pp. 138-156). USA: IGI global. https://doi.org/10.4018/978-1-61520-853-1.ch008

Teo, T. (2006). Attitudes Toward Computers: A Study of Post-secondary Students in Singapore. Interactive Learning Environments, 14(1), 17-24 .https://doi.org/10.1080/10494820600616406

Teo, T. (2009). The Impact of Subjective Norm and Facilitating Conditions on Pre-service Teachers' Attitude Toward Computer Use: A Structural Equation Modeling of an Extended Technology Acceptance Model. Journal educational computing research, 40(1), 89-109. https://doi.org/10.2190/EC.40.1.d

Teo, T. (2011). Factors Influencing Teachers' Intention to Use Technology: Model Development and Test. Computers \& Education. https://doi.org/10.1016/j.compedu.2011.06.008.

Teo, T., Wong, S. L., \& Chai, C. S. (2008). A Cross-cultural Examination of the Intention to Use Technology between Singaporean and Malaysia Pre-service Teachers: An application of the TAM. Educational \& Society, 11(4), 265-280.

Timothy, J. W. (2008). An Evaluation of the Technology Acceptance as a Means of Understanding Online Social Networking Behavior (Published Doctoral dissertation, University of South Florida, USA). Retrieved from http://scholarcommons.usf.edu/etd/568

Venkatesh, V. (2000). Determinants of Perceived Ease of Use: Integrating Control, Intrinsic Motivation, and Emotion into the Technology Acceptance Model. Information Systems Research, 11(4), 342-365. https://doi.org/10.1287/isre.11.4.342.11872

Venkatesh, V., \& Bala, H. (2008). Technology Acceptance Model 3 and a Research Agenda on Interventions. Decision Sciences, 39(2), 273-315.

Vrasidas, C., \& Glass, G. (2005). Preparing teachers to teach with technology. New York: IAP.

Wang, V. C. X. (2010). Integrating adult learning and technologies for effective education: Strategic approaches. Hershey, New York: Information Science Reference. 
Zaza, M. (2014). Factors Affecting King Khaled University Staff Members' Attitude Towards Using E-learning in the Light of a Modified Technology Acceptance Model. Journal of Arabic Studies in Education and Psychology, 49(2), 1-33.

\section{Copyrights}

Copyright for this article is retained by the author(s), with first publication rights granted to the journal.

This is an open-access article distributed under the terms and conditions of the Creative Commons Attribution license (http://creativecommons.org/licenses/by/4.0/). 